\title{
Genç İşsizlik, İhracat ve Büyüme Arasındaki İlişki: Türkiye İçin Ampirik Bir Analiz (Araştırma Makalesi)
}

\author{
The Relationship Between Youth Unemployment, Export and Economic \\ Growth: An Empirical Analysis for Turkey
}

Doi: 10.29023/alanyaakademik.889070

Mustafa KARAKUŞ

Öğr. Gör. Dr., İskenderun Teknik Üniversitesi, İskenderun Meslek Yüksekokulu, Muhasebe ve Vergi Uygulamaları Prg,

mustafa.karakus@iste.edu.tr

Orcid No: 0000-0001-7207-6686

\author{
Aslı ÖZEN ATABEY \\ Ögrr.Gör.Dr., Kahramanmaraş Sütçü Imam Üniversitesi, Sosyal Bilimler MYO, Maliye Prg., \\ aatabey@ksu.edu.tr \\ Orcid No:0000-0002-6122-1101
}

Bu makaleye atıfta bulunmak için: Karakuş, M. \& Özen Atabey, A. (2021). "Genç İssizlik, İhracat ve Büyüme Arasındaki İlişki: Türkiye İçin Ampirik Bir Analiz. Alanya Akademik Baklş”, 5(2), Sayfa No.865882.

\begin{abstract}
ÖZET
Anahtar kelimeler:

Ekonomik Büyüme,

İhracat, Genç İssizlik

Makale Geliş Tarihi: 02.03.2021

Kabul Tarihi:

05.04.2021

Ekonomik büyüme ve diğer makroekonomik değişkenler arasındaki ilişki uygulamalı literatürde sıkça ele alınan konular arasında yer almaktadır. Bu çalışma Türkiye'deki 1988-2019 donemi boyunca genç işsizlik, ihracat ve ekonomik büyüme ilişkisini inceleyerek literatüre katkl yapmak amactyla hazırlanmıştır. Çalışmanın ampirik analiz kısmında ilk olarak değiş̧enlere birim kök testleri uygulanarak durağanlıkları tespit edilmiş ve ardindan VAR modeli kurulmuştur. Daha sonra Toda-Yamamoto testi ile değişkenlerin birbirleri arasındaki nedensellik ilişkisi araştırılmıştır. Bulgular, ekonomik büyümenin ihracatı etkilediğini ancak ihracat değişkeninden ekonomik büyümeye doğru nedensellik ilişkisi bulunmadiğını göstermektedir. Bu sonuç "Büyüme Çekişli İhracat” teorisini destekler niteliktedir. İhracatın her ne kadar ekonomik büyüme üzerinde etkisi olmadiğl sonucuna ulaşılsa da genç işsizliği etkilediği tespit edilmiştir. Ayrica ampirik analiz neticesinde değişkenler arasında başka herhangi bir nedensellik ilişkisi bulunmadı̆̆ sonucuna ulaşılmıştır.
\end{abstract}

Keywords:

Economic Growth,

Exports, Youth

Unemployment

\section{ABSTRACT}

The relationship between economic growth and other macroeconomic variables is among the issues frequently discussed in the applied literature. This paper, is prepared to make a contribution to the literature by examining the relationship of youth unemployment, exports and economis growth in Turkey over the period 1988-2019. In the empirical analysis part of the study, first of all, unit root tests were applied to the variables and their stationarities 
were determined and then the VAR model was established. Then, the causality relationship between variables was investigated by Toda-Yamamoto test. The findings show that economic growth affects exports, but there is no causality relationship from export variable to economic growth. This result supports the "Growth Driven Export" theory. Although it is concluded that exports have no effect on economic growth, it has been determined that it affects youth unemployment. In addition, as a result of the empirical analysis, it was concluded that there was no other causality relationship between the variables.

\section{GIRIŞ}

Bir ülke ekonomisinde bir önceki yıla nazaran Gayri Safi Yurtiçi Hasıla (GSYİH) hacminin ve bu durumun doğal sonucu olarak ülkedeki refah düzeyinin ne kadar arttığının göstergesi, ekonomik büyüme olarak ifade edilmektedir. Ekonomik büyümeyi hedefleyen ülke ekonomileri, sanayileşme yoluyla refah seviyesini artırmaya çalışırken genellikle ulusal kaynak kıtlığıyla karşılaşmakta ve bu durumda dış kaynak kullanımına başvurmaktadır. Günümüz ülke ekonomilerinin neredeyse tamamı otarşi politikası uygulayamamakla birlikte, küreselleşmenin de etkisiyle birbirlerine bağımlı ekonomiler haline dönüşmüşlerdir. Uluslararası ekonomik ilişkilerin en önemli yollarından biri de ihracat olarak karşımıza çıkmaktadır. Geçmişten günümüze klasik iktisadi düşünürler, dış ticaretin faydalarını vurgulayarak, uluslararası ticarete dahil olan bütün ülke ekonomilerinin refah seviyelerini artırabileceklerini savunmuşlardır (Seyidoğlu, 2013: 54).

Nedensellik ilişkisi bakımından, ihracattan ekonomik büyümeye yönelik ilişsi "İhracat Çekişli Büyüme (Export-Led Growth-ELG)" şeklinde ifade edilmektedir. Diş ticaret, sermaye birikiminin öncellenerek toplam üretimin artmasına olanak tanımaktadır (Frenkel ve Romer, 1999: 394). Ülke kaynaklarının dağılımında etkinliği sağlamakla birlikte, ekonomik büyümenin hızlanmasında ihracat önemli bir rol üstlenmektedir (Perraton, 2011: 286). İhracat çekişli büyüme hipotezinde ekonomik büyümenin en önemli değişkeni ihracat artışı olarak kabul edilmektedir (Hussain ve Saaed, 2014: 364). Neo klasik iktisadi görüşe göre, ekonomik büyüme ihracattaki artışa dayandırılırken, teknoloji sistem dışında bir değişken olarak değerlendirilmiştir. İhracata dayalı ekonomik büyüme dört farklı şekilde ele alınmıştır. Bunlardan birincisi; Keynesyen iktisadi görüşü takiben kısa dönemde ihracat, dış ticaret çarpanı vasıtasıyla gelir düzeyinde artışı sağlamaktadır. İkincisi, ihracattan elde edilen dövizin, yurtiçi ve yurtdışı talebin karşılanması adına gerçekleştirilecek üretimde gereksinim duyulan girdi ithalinin finansmanında kullanılarak, üretimin artması ve ekonomik büyümenin hızlanması olarak ifade edilmektedir (Guru-Gharana, 2012: 233; Ramos, 2001:613). Üçüncü yaklaşımda ise, ihracat sayesinde rekabet artarak ölçek ekonomisinin gelişim göstermesiyle birlikte, teknolojik ilerleme ve yönetimde etkinliğin sağlanarak ekonomik büyümenin gerçekleşmesine olanak tanımaktadır (Dawson ve Sanjuán-López, 2013: 48). Dördüncü yaklaşımda ise, "İçsel Büyüme Teorisi"nde değinildiği gibi, ihracatın ekonomik büyümeye imkân tanıyan üretimde etkinliği sağlayan yöntemlerin pozitif dışsallık yaratması olarak ifade edilmektedir (Awokuse, 2007: 389-390).

İktisadi yazında, ekonomik büyümeden ihracata yönelik ilişki ise, "Büyüme Çekişli İhracat (Growth-Driven Exports-GDE)" olarak ifade edilmektedir. Büyüme çekişli ihracat, gelir düzeyi artarken yurtiçi üretim veya talepte meydana gelen bir aksaklıktan ya da teknolojideki 
ilerlemeden vb. sebeplerden meydana gelebilmektedir. Bunun tersine bazı durumlarda da ihracata konu mallara veya ticarete dahil edilmeyen mallara dönük iç talepte artış olmasıyla, ihracatta gerileme görülürken ekonomik büyümede artış görülebilmektedir (Dawson ve Sanjuán-López, 2013: 48).

Ekonomik büyümeyle ihracat arasındaki iki taraflı ilişkiyse, "İhracat Çekişli Büyüme” ve "Büyüme Çekişli İhracat" durumlarının birarada yaşandığı durumu ifade etmektedir. Uzun dönemde ihracattaki artış ekonomik büyümeye doğrudan etki ederken, ekonomik büyümeden kaynaklı üretim kapasitesi ve ölçek ekonomilerinin gelişim göstermesinden dolayı da ihracat tekrar artış göstermektedir. "Endüstri İçi Ticaret Teorisi"nde, ekonomik büyümeyle birlikte ölçek ekonomilerinde gelişim kaydedileceği, dolayısıyla verimliliğin artacağı ve ihracatın da artacağı savunulmaktadır. Özellikle piyasada az sayıda faaliyet gösteren firma bulunuyorsa, ölçek ekonomilerinde maliyetler düşüş gösterecek ve ekonomik büyüme-ihracat arasındaki neden-sonuç ilişkisi çift yönlü olarak ortaya çıkacaktır (Dawson ve Sanjuán-López, 2013: 48).

İktisat yazınında, birçok farklı yaklaşıma göre dış ticaretin faydalarının ortaya konulması, dış ticaret akımlarının ve politikalarının bir araç niteliğinde işlev görmesi büyümeye önemli katkılar sağlamıştır. Bu noktada, dünyadaki bütün ülke ekonomileri karşı karşıya oldukları kaynak kıtlığ 1 sorununu dış ticaret vasıtasıyla karşılama imkanına sahiptir. Uluslararası ticarete dahil olan ülkelerde refah düzeyinin artacağı; "Mutlak Üstünlükler Teorisinde" ve "Karşılaştırmalı Üstünlükler Teorisinde" ayrıntılı olarak açıklanmıştır. Klasik iktisadi düşünürlerden sonraki süreçte ise, "Faktör Donatımı Teorisi" ile ortaya koyulmuştur. Bu teorilerdem diş ticaret ile ekonomik büyüme arasında doğrudan ilişkiyi ortaya koyan Bhagwati'nin "Yoksullaştıran Büyüme" teorisi iktisat literatüründe oldukça önemli bir yere sahiptir. Genellikle ekonomik büyümenin refah düzeyini artırması beklentisine karşın, ticaret hadlerinde meydana gelen şiddetli bozulmalardan kaynaklı olarak ülke ekonomisinde büyüme gerçekleşirken refah düzeyinde gerilemenin olabileceği ortaya koyulmuştur (Seyidoğlu, 2013: 27-34, 82-135).

1980 yılından itibaren hemen hemen bütün dünya ülke ekonomilerinde uygulanmaya başlanan Neo liberal ekonomi politikaları, serbest piyasa ekonomisinin yaygınlık kazanmasına ve sermayenin küreselleşmesine neden olmuştur. Neo liberal ekonomi politikaları; serbest ticareti yaygınlaştırarak ülkelerde ekonomik büyümeyi sürdürülebilir kılacağı ve dolayısıyla istihdamı artırarak işsizlik sorununun kendiliğinden çözüme kavuşacağı savına dayanmaktadır. Dünya ülkeleriyle birlikte, ülkemizde de uygulanan Neo liberal ekonomi politikaları sonucunda, sermaye artışıyla birlikte ekonomik büyüme gerçekleşmiş ancak, beklenenin aksine işsizlik oranlarında önemli derecede artışlar gözlenmiştir (Bayrakdar ve İncekara, 2013: 28). Çünkü Neo liberal ekonomi politikaları, işgücü piyasasında teknolojik ilerleme ve katı işgücü yönetim tekniklerine bağlı olarak verimlilik artışı sağlamış ancak yeni istihdam alanlarına imkân tanımayan, literatürde de "istihdam yaratmayan büyüme" olarak yer bulan ekonomik büyümenin gerçekleşmesine neden olmuştur (Erdayı, 2009: 134).

Ekonomik kalkınma ve büyümenin gerçekleşebilmesi üretim faktörlerinin etkinliğinin artırılması şartına bağlanmıştır. Bu üretim faktörleri arasında en önemlisi ise, işgücünün verimliliği bakımından bazı ülkelere "demografik firsat penceresi” sunan genç işgücü potansiyelinin doğru değerlendirilmesi olarak karşımıza çıkmaktadır. Emek faktörü bakımından işgücü piyasasında genç işgücü arz ve talebi, ekonomik büyümenin temelinde yer almaktadır (Yamak vd., 2012: 41). İktisat yazınında, ekonomik büyümeyle işsizlik ilişkisi ilk defa A. Okun tarafından incelenmekle birlikte, literatüre "Okun Yasası" şeklinde geçmiştir. A. 
Okun Amerika'da 1948-1960 dönemi ekonomik büyüme ile işsizlik oranı verileri kullanarak yaptığı çalışmada, ekonomik büyümedeki bir baz puanlık artış, işsizlik oranında yarım puanlık azalışa neden olduğu sonucuna ulaşmıştır (Uslu, 2018: 1517). Ancak sonraki yıllarda yapilan iktisadi araştırmalarda, ekonomik büyüme ile işsizlik arasındaki ilişkinin ülkeden ülkeye değişiklik göstermenin yanında, her dönemde geçerli olmayabileceği sonucuna ulaşılmıştır. Yapılan bu çalışmalar, istihdam yaratmayan ekonomik büyüme teorisini gündeme getirmiş ve teoride ekonomik büyümenin bazı dönemlerde verimlilik artışı veya kapasite kullanım oranında meydana gelen artış yoluyla gerçekleşebileceği ortaya koyulmuştur (Murat ve Yılmaz Eser, 2013: 106). Dolayısıyla, mevcut işgücünün daha etkin çalıştırılması ve teknolojik yeniliklerin üretim sürecine dahil edilmesi ile emek yoğundan sermaye yoğuna dönüşen üretim stratejisi benimsenmesi nedeniyle, işsizlik oranları azalmadan da ekonomik büyümenin gerçekleşebileceği ortaya koyulmuştur (Léautier ve Hanson, 2013: 5). Diğer taraftan, işsizlik oranı ile reel milli gelirde meydana gelen değişimler arasında farklı etkileşimler gerçekleşebilmektedir. Bunlardan ilki, reel milli gelir arttı̆̆ında, bireylerin talep miktarı değişerek, iç talepte de artış gerçekleşecektir. Böylelikle, şirketlerin satış ve karlılığ 1 artış göstererek, üretim düzeyi ve istihdam uyarılabilecektir (Tejani, 2016: 845-846). İkinci durumda ise; reel milli gelirdeki yükselişten kaynaklı reel ücretler de artabilecek ve "Etkin Ücret Teorisi"ne göre emek verimliliği de artabilecektir. Yükselen işgücü verimliliğinden dolayı, yeni işgücünün istihdam edilmesine gerek kalmaksızın reel gelir seviyesi artış göstermeyi sürdürebilecektir (Kigabo ve Kamanzi, 2018: 12). Üçüncü durumda ise; reel milli gelir seviyesinden kaynaklı verimlilik ve reel ücrette meydana gelen artış, emeğin marjinal verimlilik düzeyinde artışa neden olacağından dolayı işletmelerin işgücü taleplerini artırmaya sevk ederek, işsizlik oranının düşmesine etki edebilecektir (Murat ve Yılmaz Eser, 2013: 108).

Dünyada yaşanan küreselleşme ve liberalizasyon sürecine, Türkiye de bu 24 Ocak 1980 kararları ile dahil olmuştur. Türkiye ekonomisi açısından yapısal değişimleri içeren bu kararlar sonucunda, dış ticaretin önündeki önemli engeller kalkmış, ekonomik büyüme ve sanayileşme stratejileri ihracata yönelik kurgulanmış ancak 2000 y1lına kadarki süreçte istikrarlı bir ekonomik büyüme gerçekleşememiştir. 2000 yılından 2002 yllına kadarki süreçte uygulanan enflasyonla mücadele programının başarılı olmaması ve küresel ekonomik krizlerin de etkisiyle Türkiye ekonomisinde 2002 yılına değin istikrarlı bir ekonomik büyüme yakalanamamıştır. 2002 yılından itibaren yapısal ekonomik reformları içeren "Güçlü Ekonomiye Geçiş Programı" uygulanmaya başlanmıştır. Türkiye ekonomisi, 2002-2006 döneminde uzun bir aradan sonra istikrarlı bir ekonomik büyümeyi gerçekleştirmekle birlikte, dış ticarette de önemli gelişmeler kaydedilmiştir (Şahin, 2014, 120-274). Türkiye ekonomisi, cari açık, yüksek işsizlik oranları ve dış borçlar gibi birçok sorunu tam manasıyla çözüme kavuşturamamış olsa da planlanan yapısal reformları hayata geçirmiş, makroekonomik istikrarı sağlamakla birlikte finansal piyasalarında güçlü bir yapı ortaya koyabilmiştir. Böylelikle, 2008 yılında yaşanan küresel ekonomik krizini diğer ülke ekonomilerine nazaran daha az etkilenmiş hatta krizi firsata çevirebilecek bir ekonomik performans ortaya koymuştur (Kaderli ve Küçükkaya, 2012: 95). Güçlü ekonomiye geçiş programında dışa açık ekonomi politikaları aracılı̆̆ıyla genç istihdamının artırılması hedeflenmiştir. Ancak, Türkiye ekonomisinde mikro ve makroekonomik gelişimler genel olarak değerlendirildiğinde, dış ticaret hacminin genç istihdamı ve katma değer yaratımı bakımından etkisinin sınırlı kaldığı anlaşılmaktadır (Yükseler ve Türkan, 2008: 163).

Ekonomik büyüme, ihracat ve genç işsizlik ilişkisi gelişmekte olan ülke ekonomileri bakımından üzerinde hassasiyetle durulması ve etkili politikalar üretilmesi gereken en önemli 868 
konular arasında görülmektedir. Gelişmekte olan ülke ekonomileri, finansal küreselleşmenin arttığı günümüzde, ülkeye sıcak paranın girişini sağlayabilmek adına düşük kur, yüksek faiz politikasını benimsemişlerdir. Ancak uygulanmakta olan bu politikalardan dolayı diş ülkelerden sağlanan girdilerin maliyeti düşerken, yurtiçi üretim olumsuz etkilenmektedir. Yurtiçi sanayi üretiminin ithalata bağlılık seviyesinin artış göstermesi ve yerli üretim gücünün düşmesiyle neticelenen bu akım dolayısıyla işsizlik de artış göstermektedir. Üretimden ziyade tüketimin öne çıkmasıyla tasarruf yetersizliği de ortaya çıkmakta ve tasarruf yetersizliği ise makroekonomik sorunların başında yer alan cari açığı artırmaktadır (Çiftçi ve Çapkın, 2013: 162). Gelişmiş ülke ekonomileri, istihdam politikalarında bilgi toplumunun gereksinimlerine yönelik kalifiye işgücünü yetiştirme gayretindeyken, Türkiye gibi gelişmekte olan ülke ekonomileri bu değişim sürecinden kaynaklanan sorunlarla birlikte, bilgi toplumu ihtiyaçlarıyla ortaya çıkan yeni problemlerle de mücadele etmek zorunda kalmaktadırlar. Bu kapsamda, işgücü piyasasına yeni giren ve işgücü piyasasının aradığı niteliklere sahip olmayan dezavantajlı grupların istihdama dahil olamaması, bu gruplar içerisinde işsizlik oranları oldukça yüksek düzeyde seyreden 15-24 yaş gurubunu kapsayan genç işsizlik sorunu önemli bir sosyo-ekonomik sorun olarak karşımıza çıkmaktadır (Ata, 2007: 112). Makro düzeyde genç işsizlik politikalarının başarıya ulaşması, göreceli olarak yüksek ve istikrarlı bir ekonomik büyümenin gerçekleşmesi şartına bağlanmaktadır. Ekonomide istikrar sağlanması durumunda, istikrarlı yüksek ekonomik büyüme ve genç istihdamı artışıyla birlikte, ihracata yönelik sanayileşme de mümkün görülmektedir (Gürsel ve Ulusoy, 1999: 136-137).

$\mathrm{Bu}$ çalışmada, Türkiye ekonomisi açısından, ekonomik büyüme sürecinin önemli kaynakları arasında görülen ihracat ve demografik firsat penceresi sunması bakımından genç işsizliği ilişkisine odaklanılmaktadır. Çalışmada bu kapsamda, 1988-2019 zaman aralığında Türkiye'deki genç işsizlik, ihracat ve ayrıca ekonomik büyüme değişkenleri arasındaki ilişkinin analizi yapılmaktadır. Söz konusu çalışmanın giriş bölümünde teorik ve kavramsal çerçeve ortaya koyulurken, sonrasında konuyla ilgili literatür araştırması yapılmakta ve daha sonra ise, Türkiye ekonomisi açısından 1988-2019 yıllarına ilişkin olarak ekonomik büyüme, ihracat ve genç işsizlik ilişkisinin nedensellik analizlerine yönelik bulgular açıklanarak, sonuç bölümüyle sonuçlandırılmaktadır.

\section{LITERATÜR TARAMASI}

Literatürde genç işsizlik, ihracat ve ekonomik büyüme arasındaki ilişkiyi inceleyen çok sayıda çalışma bulunmamaktadır. Bu konudaki sınırlı sayıdaki çalışmalardan biri Akyol'un (2020) E7 ülkelerindeki işsizlik, ihracat ve ekonomik büyüme ilişkisini araştırdığı çalışmadır. 20002016 yılları arasındaki dönemi kapsayan yıllık veriler kullanılarak Panel Granger nedenselliğin araştırıldığı çalışmada, Dumitrescu Hurlin testi kullanılmış olup, ekonomik büyüme değişkeninden ihracata ve işsizlik oranı değişkeninden ekonomik büyümeye doğru tek taraflı nedensellik korelasyonunun olduğuna dair sonuçlar elde edilmiştir.

İhracat, ülkelere döviz girişi sağlamakla birlikte faktör verimliliğini de artırmaktadır. Ölçek ekonomileri ve pozitif dışsallıklar sayesinde sağlanan kazanç artışlarının yanı sıra, ara ve yatırım malları ithalatında kolaylık yaratan, maliyet tasarrufuna yol açan ihracat, ayrıca istihdamda artışa neden olmaktadır. Tüm bu gibi nedenlerden ötürü ekonomik büyüme oranının arttırılabilmesi için toplam ihracatın arttırılması gerekliliği savunulmaktadır (Acaravcı ve Kargı, 2015: 2). Yapılan bilimsel araştırmaların bazıları ihracatın ekonomik büyümeye olumlu katkısı olduğu sonucuna ulaşmışken, bazıları da böyle bir ilişkinin mevcut olmadığına dair 
sonuçlara ulaşmışlardır. Konuyla ilgili çalışmalardan birini yapan Saraç (2013), 1989-2011 dönemini kapsayan süreçte Türkiye'ye ait çeyreklik verileri kullanarak, doğrusal olmayan ekonometrik yöntemlerle inceleme yapmıştır. Çalışma neticesinde ithalat ve ihracatın, ekonominin gerek daralma gerekse genişleme süreçlerinde ekonomik büyümeye olumlu yönde etki ettiği bulgusuna ulaşmıştır. Aytaç (2017) tarafından 2001-2016 dönemi Türkiye ekonomisi için ekonomik büyüme ile ihracat ilişkisinin araştırıldığı çalışmada, Granger nedensellik testi kullanılmış ve ihracat değişkeninden büyümeye doğru olmasa da ekonomik büyüme değişkeninden ihracat değişkenine doğru Granger nedensellik ilişkisinin tek yönlü olduğuna dair sonuçlar raporlanmıştır.

Yapraklı (2007) 1970-2005 yıllarında Türkiye ekonomisi için temel sektörlere yönelik ihracatla ekonomik büyüme ilişkisini eşbütünleşme testinin yanı sıra Granger nedensellik testleri yardımıyla tespit etmeye çalışmıştır. Çalışmada toplam ihracatın ve sanayi ürünleri ihracatının ekonomik büyümeyi olumlu etkilediği şeklinde yorumlanabilecek tek yönlü pozitif bir nedensonuç ilişkisinin tespit edilirken tarım ve madencilik ürünleri ihracatı ve ekonomik büyüme arasında çift taraflı neden-sonuç ilişkisi bulunduğu tahmin edilmiştir. Bilgin ve Şahbaz (2009), Türkiye'ye ait 1987-2007 dönemine ait ihracat ve ekonomik büyüme ilişkisini araştırmışlardır. Johansen Eşbütünleşme, Granger ve Toda-Yamamoto Nedensellik testlerinin yapıldığ 1 çalışmaya ait ihracatın ekonomik büyüme üzerinde güçlü bir etkisi olduğu sonucu, ihracata dayalı büyüme olgusunun doğruluğunu kanıtlar niteliktedir. Aktaş (2009) 2009 yılında yaptığ 1 çalışmada 1996-2006 dönemini kapsayan süreçte Türkiye'deki ithalat, ihracat ve ekonomik büyüme değişseleri arasındaki olası ilişkiyi ampirik olarak incelemiştir. Johansen'ın Eşbütünleşme testi uygulanılan çalışmada bu üç değişken arasında uzun dönem denge ilişkisinin olduğu ve Hata Düzeltme Modeli ile ihracat, ithalat ve ekonomik büyüme değişkenleri arasında kısa dönemde çift taraflı ilişki olduğuna dair sonuçlar elde edilmiştir. Ayrıca uzun dönemde, ihracat değişkeninden ithalata, ithalattan ihracat değişkenine, ekonomik büyümeden ihracat değişkenine ve ekonomik büyümeden ithalata doğru tek yönlü nedensellik ilişsisi bulunduğu çalışmada elde edilen sonuçlar arasında yer almaktadır. Demirhan (2005) 1990-2004 dönemini kapsayan çalışmasında Türkiye'deki ihracat ve büyüme ilişkisini Johansen Eşbütünleşme ve Vektör hata düzeltme modeli yardımıyla araştırmıştır. Bulgular, değişkenler arasındaki ilişkinin uzun dönemde geçerli olduğu yönündedir. Ayrıca ihracat değişkeninden ekonomik büyümeye doğru nedensellik ilişkisi olmadığı ancak ithalattan büyümeye doğru ise nedenselliğin bulunduğu çalışmada elde edilen sonuçlar arasındadır. Türkiye'ye ait bu çalışmaların yanı sıra Rangasamy (2009) Güney Afrika için ihracatın ekonomik büyüme üzerindeki etkisini Eşbütünleşme ve Granger Nedensellik Testi ile araştırmış̧ır. İhracatın ekonomik büyüme rakamlarını tek yönlü olarak etkilediğinin tespit edildiği çalışmada, ihracatı arttıran bilinçli politikalar üretilmesi gerektiği savunulmuştur. Temiz ve Gökmen (2010), Türkiye'deki ihracat-ekonomik büyüme ilişkisini 1950-2009 dönemine ait verileri kullanarak araştırmışlardır. Johansen eşbütünleşme testi ve vektör hata düzeltme modeli iki değişken arasında kısa ve uzun dönem ilişsisinin tespit edildiği çalışmada, ekonomik büyümeden ihracata doğru Granger nedensellik ilişkisi olduğu sonucuna ulaşılmıştır. BajoRubio ve DíazRoldán (2012) 2004 yılında Avrupa Birliği’ne 2004 yllında katılan sekiz ülkedeki (Çek Cumhuriyeti, Slovakya, Estonya, Polonya, Letonya, Macaristan, Litvanya, Slovenya) ihracat ve ekonomik büyüme arasındaki ilişkiyi Eşbütünleşme testi ile birlikte Granger nedensellik testi ile araştırmışlardır. 1996-2009 dönemini kapsayan verilerle yapılan analiz sonuçları, Çek Cumhuriyeti'nde ihracatın ekonomik büyümeyi tek taraflı olarak etkilediği ancak diğer ülkelerde ihracattaki artışın ekonomik büyümeyi desteklemediği ve 
ekonomik büyümenin de ihracatı desteklemediğini yönündedir. İzgi ve Yılmaz (2018) 19922016 döneminde ithalat, ihracat ve ekonomik büyüme arasındaki ilişkiyi Türkiye'ye ait verileri kullanarak araştırmıştır. Johansen eşbütünleşme ve Granger nedensellik testlerinin kullanıldığ1 çalışma neticesinde ihracatın ekonomik büyümeyi tek yönlü olarak etkilediği sonucuna ulaşılarak ülkenin ihracata dayalı büyüme stratejisini izlemesi gerektiğine dair politika önerilerinde bulunulmuştur.

Her ne kadar literatürde ekonomik büyüme oranları ile işsizlik oraları arasında ters yönlü ilişki olduğu kabul görmüş olsa da uygulamada bunu kanıtlayan sonuçlar olduğu kadar tersini iddia eden sonuçlar da mevcuttur. Bağc1 ve Börü (2018), Türkiye'deki ekonomik büyüme ile işsizlik arasındaki ilişkiyi teorik ve ampirik olarak 1960-1979, 1980-1999, 2000-2016 olmak üzere üç farklı dönemi baz alarak Granger Nedensellik Testi ile incelemişlerdir. Yapılan çalışmada 1960-1979 ve 1980-1999 dönemleri için ekonomik büyümenin işsizliği tek taraflı etkilediği, ekonomik büyümenin işsizliği az miktarda düşürdüğü tespit edilmiştir. 2000-2016 döneminde ise işsizlikten ekonomik büyümeye doğru tek taraflı nedensellik ilişkisinin olduğu, işsizliğin ekonomik büyümeyi zayıf da olsa olumsuz etkilediği sonucuna ulaşılmıştır. Bağcı ve Börü (2018) bu sonuçlar neticesinde ekonomik büyümenin istihdam yaratan, yüksek katma değere sahip ürünlerin üretimine odaklı ve dışa bağımlılığı minimum düzeye indirecek ihracat politikasını kapsayan büyüme modeli ile sağlanabileceğine dair politika önerilerinde bulunmuşlardır. Takım (2010), 1975-2008 yılları arasında Türkiye'deki "istihdamsız büyüme” olgusundan yola çıkarak ekonomik büyüme-işsizlik ilişkisini Granger Nedensellik analizi yardımıyla araştırmıştır. Çalışma neticesinde ekonomik büyümenin işsizliği ve işsizliğin de ekonomik büyümeyi etkilediğine dair sonuçlar elde edilmiş ve verimli bir şekilde faaliyet gösteren işgücünün ekonomik büyüme rakamlarını pozitif yönde etkileyeceği iddia edilmiştir. Arı (2016) Türkiye'de ekonomik büyüme ile işsizlik arasında 1980-2014 dönemi için uzun dönemli bir ilişkinin olup olmadığını Bayer ve Hanck Eşbütünleşme testi ile araştırmıştır. Ayrıca Arı'nın Hacker ve Hatemi-J yardımıyla ekonomik büyüme-işsizlik nedensellik ilişkisini araştırdığı çalışma bulguları, işsizlik ve ekonomik büyüme arasında ne uzun dönemli bir ilişki ne de nedensellik ilişkisi olduğunu göstermiştir. Akcan (2018) 2000-2017 dönemine ait üç aylık verileri kullanarak Türkiye'deki işsizlik ekonomik büyüme ilişkisini tespit etmek amaciyla Granger nedensellik testini kullanmıştır. Yapılan ampirik analizler, bu iki değişkenin birbirini çift yönlü etkilediğini yani ekonomik büyüme ve işsizlik arasında çift yönlü nedensellik ilişkisi olduğunu destekler niteliktedir. Muratoğlu (2011) 2000-2011 dönemi Türkiye ekonomisindeki ekonomik büyüme ve istihdam ilişkisini araştırdığı çalışmasında Engle Granger Eş Bütünleşme Testi ve Granger Nedensellik Testi kullanmıştır. Yapılan testlerin sonucu, iki değişken arasında uzun dönemli bir ilişki olmadığını ayrıca aralarında nedensellik ilişkisi bulunmadığını göstermiştir. Türkiye'ye ait bu çalışmaların yanı sıra Kreishan (2011) ise 1970-2008 dönemi için Ürdün'deki işsizlik ve ekonomik büyüme ilişkisini eşbütünleşme testi ile araştırdı̆̆ 1 çalışmasında ekonomik büyüme sorununun işsizlik olgusunu açıklayamadığı sonucuna ulaşmıştır.

Villaverde ve Maza (2009), 1980-2004 dönemi için Kuadratik, Hodrick-Prescott ve BoxterKing filtreleme yöntemlerini kullanarak İspanya'daki bölgelerde Okun Kanun'unun geçerliliğini diğer bir deyişle işsizlik ekonomik büyüme ilişkisini araştırmıştır. Çalışma neticesinde tüm İspanyol bölgelerinde söz konusu kanunun geçerli olduğu tespit edilmiş ancak her bölgede Okun katsayısının farklılık gösterdiği belirlenmiştir. Huang ve Lin (2008), ABD’ye ait 1948-2006 dönemine ait üç aylık verileri kullanarak işsizlik ile ekonomik büyüme arasındaki ilişkiyi incelemişlerdir. Okun Kanun'unun tüm zaman dilimlerinde geçerli olduğu 
yani işsizlikteki artışın ekonomik büyümeyi olumsuz etkilediği tespit edilen çalışmada ayrıca Okun katsayısının zamanla değişim gösterdiği tespit edilmiştir.

Göçer ve Erdal (2015), genç işsizlik oranı AB ortalamasının üzerinde olan 18 Merkezi ve Doğu Avrupa ülkesi için genç işsizlik ve ekonomik büyüme ilişkisini 2006-2012 dönemi için araştırmışlardır. Çalışma kapsamında yapılan panel eşbütünleşme testleri sonucunda ortalamanın üzerinde bir ekonomik büyüme genç işsizliği azaltmaktadır. Ancak tahmin sonuçlarına dayanılarak, ekonomik büyümenin, \%50-60 gibi oldukça yüksek genç işsizlik oranlarına sahip bu ülkelerde genç işsizliği sorununu tek başına çözebilecek kadar güçlü bir etkiye sahip olmadığ 1 belirtilmiştir. Katumo ve Maingi (2020), Kenya'daki ekonomik büyümegenç işsizlik ilişkisini 1991-2015 dönemi için incelemişlerdir.Yapılan Granger ve OLS testleri sonucunda Kenya ekonomisinde genç işsizliği bağlamında Okun kanunun geçerli olmadığ sonucuna ulaşılmıştır.

Uluslararası ekonomi literatürü dış ticaret politikalarının ekonomik büyümeyi etkilediği yönünde görüşleri destekler niteliktedir. Başarılı bir ihracat politikası üretimde artış yaratarak hasılayı ve istihdamı arttırabilmektedir. Bu konuyla ilgili çalışma yapanlardan Çütcü ve Cenger (2017), 2005-2017 dönemi aylık verilerini baz alarak dış ticaret ve işsizlik arasındaki ilişkiyi Gregory-Hansen Eşbütünleşme Testinin yanı sıra Toda-Yamamoto Nedensellik analizi ile araştırmışlardır. İhracat, ithalat ve işsizlik arasında uzun dönemli bir ilişkinin bulunmadığına dair elde edilen çalışma sonuçları ayrıca ihracat değişkeninden ithalata doğru nedensellik ilişkisi olmasa da diğer değişkenler arasında bir nedensellik ilişkisi bulunduğunu göstermiştir. Akcan ve Ener (2018), 2000-2015 döneminde Türkiye'ye ait üçer aylık verileri kullanarak yaptıkları Varyans Ayrıştırması ve Etki-Tepki Analizi neticesinde işsizliğin ihracata olan etkisinin her dönem pozitif olduğu sonucuna ulaşmışlardır. Altay ve Yılmaz (2016), 2005-2015 dönemi Türkiye ekonomisindeki ihracat ve istihdam ilişkisini incelemişlerdir. Maki çoklu yapısal kırılmalı eşbütünleşme testi ve Tam Düzeltilmiş En Küçük Kareler (FMOLS) yönteminin kullanıldığı çalışma sonuçları, ihracat ve istihdam değişkenleri arasında uzun vadeli, pozitif yönlü bir ilişki olduğunu ortaya koymuştur. Ayhan (2018), Türkiye ekonomisine ait 2005-2014 yılları arasındaki aylık verileri kullanarak dış ticaret-istihdam ilişkisini incelemiştir. Sınır Testi yaklaşımı ile değişkenler arasında eşbütünleşme ilişkisi tespit edilmiş olup ARDL (Autoregresive Distributed Lags) modeli ile yapılan analiz sonucunda ihracat değişkeninin istihdam düzeyini olumlu, ithalatın ise istihdamı olumsuz yönde etkilediği görülmüştür. Gül ve Kamacı (2012), ABD, Japonya Almanya, Kanada, Avustralya, Hollanda, İtalya, İngiltere, İspanya İrlanda, İsviçre ve Güney Kore'yi kapsayan 12 gelişmiş ülkede 19802010 dönemi için ve Letonya, Litvanya, Şili, Kazakistan, Meksika, Romanya ve Türkiye'nin dahil olduğu 7 gelişmekte olan ülkede ise 1993-2010 dönemi için dış ticaretin istihdam üzerindeki etkisini incelemişlerdir. Pedroni eşbütünleşme testinin yanı sıra Granger nedensellik testi yapılan çalışma neticesinde hem gelişmiş hem de gelişmekte olan ülkelerde, işsizlik değişkeninden ne ithalat ne de ihracata doğru bir ilişki tespit edilebilmiştir. Ancak ithalat ve ihracat değişkenlerinden işsizliğe doğru tek taraflı bir nedensellik ilişkisinin mevcut olduğu sonucuna ulaşılmıştır.

\section{AMPIRIKK UYGULAMA}

\subsection{Uygulamanın Amacı, Veri ve Model}

Bu çalışma 1988-2019 zaman aralığında Türkiye ekonomisinde genç işsizlik, ihracat ve ekonomik büyüme arasındaki ilişkinin tespit edilmesi amaçlanarak hazırlanmıştır. Genç işsizlik 
(YU) göstergesi olarak 15-24 yaş arasındaki toplam işgücü içerisindeki genç işsizlerin pay1, ihracat (EXP) göstergesi olarak toplam mal ve hizmet ihracatının GSYİH içerisindeki payı ve ekonomik büyüme (GDP) göstergesi olarak da GSYİH'nın yıllık artış oranı kullanılmıştır. Modelde kullanılan değişkenlere ait yıllık veriler Dünya Bankası (WB) resmi internet sitesi veri tabanından elde edilmiş olup ampirik analizler E-views 10 programı aracılığıyla yapilmıştır.

\subsection{Yöntem ve Uygulama Sonuçları}

\subsubsection{Birim Kök Testleri}

Zaman serisinde ortalama ve varyans zamandan bağımsız ve kovaryansı iki farklı dönem arasındaki uzaklığa bağlı ise bu serinin durağan olduğu varsayılır (Çakmur Yıldırtan, 2017: 242). Şayet seri $d$ kez fark alınmasından sonra durağanlaşıyorsa serinin $d$. dereceden bütünleşik olduğu kabul edilir. Durağan olmayan serilerle kurulan regresyon modellerinin tahmininde sahte sonuçlar hesaplanabileceği için ekonometrik analizler yapılmadan önce seriler durağan hale getirilmelidir (Akdi, 2003: 3).

$\mathrm{Bu}$ çalışmada genç işsizlik (YU), ihracat (EXP) ve ekonomik büyüme (GDP) değişkenlerine ait serilerin durağanlığının tespiti için Dickey ve Fuller'in (1981) geliştirdiği Genişletilmiş Dickey-Fuller (ADF: Augmented Dickey-Fuller) ve Phillips ve Perron'un (1988) geliştirdiği Philips-Perron (PP) Testi uygulanmıştır.

Tablo 1, genç işsizlik (YU), ihracat (EXP) ve ekonomik büyüme (GDP) serilerinin durağanlığ1 yani serilerin birim kök içerip içermediğine dair ADF birim kök testine ait sonuçları içermektedir.

Tablo 1. Augmented Dickey Fuller (ADF) Birim Kök Testi Sonuçları

\begin{tabular}{|c|c|c|c|c|}
\hline \multirow{3}{*}{ Değişkenler } & \multicolumn{4}{|c|}{ Sabitli } \\
\hline & \multicolumn{2}{|c|}{ I (0) } & \multicolumn{2}{|c|}{$\mathbf{I}(\mathbf{1})$} \\
\hline & $\begin{array}{c}\text { t-İstatistik } \\
\text { değeri }\end{array}$ & $\begin{array}{c}\text { Kritik değer* + } \\
\text { [p. değeri] }\end{array}$ & $\begin{array}{c}\mathrm{t} \text {-İstatistik } \\
\text { değeri }\end{array}$ & $\begin{array}{c}\text { Kritik değer* } \\
\text { [p. değeri] }\end{array}$ \\
\hline GDP & -5.865878 & $\begin{array}{c}-3.661661 \\
{[0.0000]}\end{array}$ & -9.710545 & $\begin{array}{c}-3.670170 \\
{[0.0000]}\end{array}$ \\
\hline EXP & -0.935502 & $\begin{array}{c}-3.661661 \\
{[0.7631]}\end{array}$ & -5.056101 & $\begin{array}{c}-3.679322 \\
{[0.0003]}\end{array}$ \\
\hline \multirow[t]{4}{*}{ YU } & -1.136989 & $\begin{array}{c}-3.661660 \\
{[0.6882]} \\
\end{array}$ & -4.363024 & $\begin{array}{c}-3.670170 \\
{[0.0018]}\end{array}$ \\
\hline & \multicolumn{4}{|c|}{ Sabitli ve Trendli } \\
\hline & \multicolumn{2}{|c|}{ I (0) } & \multicolumn{2}{|c|}{$\mathbf{I}(\mathbf{1})$} \\
\hline & $\begin{array}{c}\text { t-İstatistik } \\
\text { değeri }\end{array}$ & $\begin{array}{c}\text { Kritik değer* + } \\
\text { [p. değeri] }\end{array}$ & $\begin{array}{c}\text { t-İstatistik } \\
\text { değeri }\end{array}$ & $\begin{array}{l}\text { Kritik değer* } \\
\text { [p. değeri] }\end{array}$ \\
\hline GDP & -5.819112 & $\begin{array}{c}-4.284580 \\
{[0.0002]}\end{array}$ & -9.601018 & $\begin{array}{c}-4.296729 \\
{[0.0000]}\end{array}$ \\
\hline EXP & -2.854632 & $\begin{array}{c}-4.296729 \\
{[0.1904]}\end{array}$ & -4.973969 & $\begin{array}{c}-4.309824 \\
{[0.021]}\end{array}$ \\
\hline $\mathbf{Y U}$ & -2.211353 & $\begin{array}{c}-4.284580 \\
{[0.4671]}\end{array}$ & -4.422619 & $\begin{array}{c}-4.296729 \\
{[0.0074]}\end{array}$ \\
\hline
\end{tabular}

Not: * değeri Mac Kinnon (1996) kritik değerleri \% 1 anlamlılık düzeyine göre alınmıştır. Köşeli parantez içerisinde ifade edilen değerler olasılık değerlerini ifade etmektedir. 
Tablo 1'e göre; ekonomik büyüme değişkeni (GDP) hem sabitli hem de sabitli ve trendli modelde düzey değerlerinde durağandır. Fakat ihracat (EXP) ve genç işsizliği (YU) değişkenleri düzey değerlerinde durağan olmayıp birinci farkları alındığında durağan hale gelmektedir.

Tablo 2. Philips-Perron (PP) Birim Kök Testi Sonuçları

\begin{tabular}{|c|c|c|c|c|}
\hline \multirow{3}{*}{ Değiş̧kenler } & \multicolumn{4}{|c|}{ Sabitli } \\
\hline & \multicolumn{2}{|c|}{ I (0) } & \multicolumn{2}{|c|}{$\mathbf{I}(\mathbf{1})$} \\
\hline & $\begin{array}{c}\text { t-İstatistik } \\
\text { değeri }\end{array}$ & $\begin{array}{c}\text { Kritik değer* }+ \\
\text { [p. değeri] }\end{array}$ & $\begin{array}{c}\text { t-İstatistik } \\
\text { değeri }\end{array}$ & $\begin{array}{c}\text { Kritik değer* } \\
\text { [p. değeri] }\end{array}$ \\
\hline GDP & -6.007541 & $\begin{array}{c}-3.661661 \\
{[0.0000]}\end{array}$ & -17.98991 & $\begin{array}{c}-3.670170 \\
{[0.0001]}\end{array}$ \\
\hline EXP & -0.777812 & $\begin{array}{c}-3.661661 \\
{[0.8114]}\end{array}$ & -6.413462 & $\begin{array}{c}-3.670170 \\
{[0.0000]}\end{array}$ \\
\hline \multirow[t]{4}{*}{ YU } & -1.054096 & $\begin{array}{c}-3.661661 \\
{[0.7209]}\end{array}$ & -4.084113 & $\begin{array}{c}--3.670170 \\
{[0.0036]}\end{array}$ \\
\hline & \multicolumn{4}{|c|}{ Sabitli ve Trendli } \\
\hline & \multicolumn{2}{|c|}{ I (0) } & \multicolumn{2}{|c|}{ I(1) } \\
\hline & $\begin{array}{c}\text { t-İstatistik } \\
\text { değeri }\end{array}$ & $\begin{array}{c}\text { Kritik değer* } \\
\text { [p. değeri] }\end{array}$ & t-İstatistik & $\begin{array}{c}\text { Kritik değer*+ } \\
\text { [p. değeri] }\end{array}$ \\
\hline GDP & -6.287315 & $\begin{array}{c}-4.284580 \\
{[0.0001]}\end{array}$ & -17.66111 & $\begin{array}{c}-4.296729 \\
0.0000\end{array}$ \\
\hline EXP & -2.770557 & $\begin{array}{c}-4.284580 \\
{[0.2179]}\end{array}$ & -6.083674 & $\begin{array}{c}-4.296729 \\
{[0.0001]}\end{array}$ \\
\hline YU & -1.610257 & $\begin{array}{c}-4.284580 \\
{[0.7656]}\end{array}$ & -5.172580 & $\begin{array}{c}-4.296729 \\
{[0.0012]}\end{array}$ \\
\hline
\end{tabular}

Not: * Mac Kinnon (1996) kritik değerleri \% 1anlamlılık düzeyine göre alınmıştır. Köşeli parantez içerisinde ifade edilen değerler olasılık değerlerini göstermektedir.

Tablo 2, genç işsizlik (YU), ihracat (EXP) ve ekonomik büyüme (GDP) serilerine ait PP birim kök testlerinin sonuçlarını göstermektedir. PP birim kök testi bulguları; ekonomik büyüme değişkeninin (GDP) hem sabitli modelde hem de sabitli ve trendli modelde düzey değerlerinde durağan olduğunu ancak ihracat (EXP) ve genç işsizliği (YU) değişkenlerinin birinci farkları alındığında durağan hale geldiğini göstermektedir. PP birim kök testine ait sonuçlar ADF testi ile paralel sonuçlar içermektedir.

\subsubsection{Toda-Yamamoto (1995) Nedensellik Analizi}

Veriler arasındaki nedensellik ilişkisinin tespitinde kullanılan geleneksel Granger (1969) Nedensellik Testinde serilerin durağan olması şartı aranmaktadır. Ancak düzey değerlerinde durağan olmayan serilerin farkı alındığında bilgi kaybı ortaya çıkmaktadır. VAR (Vector Autoregression) modelinin temeline dayanan Toda-Yamamoto'nun (1995) geliştirdiği testte ise serilerin durağan olup olmaması dikkate alınmaz. Dolayısıyla söz konusu test, serilerin düzey değerleri kullanılarak modelin tahmin edilmesine imkan tanır (Toda-Yamamoto, 1995: 225250).

Toda-Yamamoto Nedensellik testinde ilk olarak serilere birim kök testleri uygulanılarak en yüksek durağanlaşma derecesi $\left(\mathrm{d}_{\max }\right)$ belirlenmelidir. Ardından kurulacak VAR modeli yardımıyla optimal gecikme uzunluğu $(\mathrm{m})$ tespit edilip, belirlenen gecikme uzunluğuna $(\mathrm{m})$ en yüksek durağanlaşma derecesi $\left(\mathrm{d}_{\max }\right)$ ilave edilerek $\mathrm{m}+\mathrm{d}_{\max }$ belirlenir (Çil Yavuz, 2006: 169). 
Tablo 3: Bilgi Kriterlerine Göre En Uygun Gecikme Uzunluğu

\begin{tabular}{|l|c|c|c|c|c|c|}
\hline Lag & LogL & LR & FPE & AIC & SC & HQ \\
\hline 0 & -223.2819 & NA & 2099.489 & 16.16299 & 16.30573 & 16.20663 \\
\hline 1 & -193.2185 & 51.53717 & $469.0627^{*}$ & $14.65846^{*}$ & $15.22941^{*}$ & $14.83301^{*}$ \\
\hline 2 & -190.0592 & 4.738991 & 731.0639 & 15.07566 & 16.07481 & 15.38111 \\
\hline 3 & -185.3691 & 6.030078 & 1062.801 & 15.38351 & 16.81087 & 15.81987 \\
\hline 4 & -168.6065 & $17.95999^{*}$ & 696.6289 & 14.82903 & 16.68460 & 15.39630 \\
\hline
\end{tabular}

* Ardışık modifiye edilmiş LR test istatistiği (LR), Son Tahminci Hatası (FPE), Akaike Bilgi Kriteri (AIC), Schwarz Bilgi Kriteri (SC), Hannan-Quinn Bilgi Kriteri (HQ) tarafindan seçilen optimum gecikme uzunluğu göstermektedir.

Tablo 3, VAR modeli aracılığıyla beş farklı kritere göre optimal gecikmeleri göstermektedir. Son Tahminci Hatası (FPE), Akaike (AIC) Bilgi Kriteri, Schwarz Bilgi Kriteri (SC) ve HannanQuinn Bilgi Kriteri'ne (HQ) göre optimal gecikme uzunluğu 1 iken Ardışık Modifiye Edilmiş LR test istatistiği (LR) kriterine göre 4'tür. Bu sonuçlardan yola çıkarak çalışma kapsamında kurulan VAR modeli, bilgi kriterlerinin çoğunun işaret ettiği optimal gecikme uzunluğu (m) olan 1 dikkate alınarak tahmin edilmiştir.

Tahmin edilen VAR modelinin durağanlık koşulunu sağlayıp sağlamadığı ve modelde otokorelasyon sorununun bulunup bulunmadığının tespiti de önemlidir.

Inverse Roots of AR Characteristic Polynomial

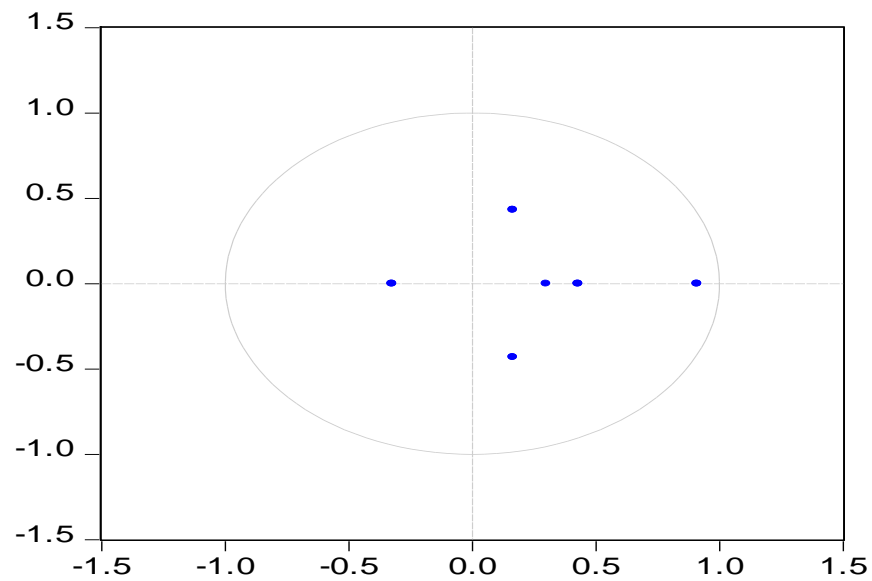

Şekil 1. AR Karakteristik Polinomunun Ters Köklerinin Birim Çember İçindeki Konumları

VAR modelinin durağanlığı, katsayı matrisinin öz değerlerine bağlı olup eğer öz değerlerin tamamı birim çemberin içerisinde bulunuyorsa modelin durağan olduğu kabul edilmektedir. Şayet katsayı matrisinin öz değerlerinden bir tanesi bile birim çemberin dişında bulunuyorsa sistem durağan değildir (Hendry ve Juselius, 2001: 10).

Şekil 1 ve Tablo 4, tespit edilen optimal gecikme uzunluğu (m) 1 ile kurulan VAR modeline göre oluşturulmuş AR Karakteristik Polinomunun Ters Köklerinin dağılımını ve değerlerini göstermektedir. Şeklin ortaya koyduğu gibi modeldeki bütün değişkenlerin AR polinomunun 
ters kökleri birim çemberin içerisinde bulunmaktadır. Ayrıca tablodan görüldüğü gibi hiçbir modülüs değeri referans aralığının dışında değildir. Dolayısıyla model istikrarlı bir modeldir.

Tablo 4. AR Karakteristik Polinomunun Ters Kökleri

\begin{tabular}{|c|c|}
\hline Kök & Modulus \\
\hline 0.910566 & 0.910566 \\
\hline $0.165651-0.431668 \mathrm{i}$ & 0.462361 \\
\hline $0.165651+0.431668 \mathrm{i}$ & 0.462361 \\
\hline 0.428625 & 0.428625 \\
\hline-0.324146 & 0.324146 \\
\hline 0.300318 & 0.300318 \\
\hline
\end{tabular}

Kurulan VAR modelinde otokorelasyon sorununun tespiti ise LM Testi ile sınanmış olup sonuçlar Tablo 5'te raporlanmıştır. Tablo 7'den görüldüğü üzere olasılık değerlerinin 0.05 'den daha büyük değerler olması modelde otokorelasyon sorununun olmadığı anlamına gelmektedir. Dolayısıyla tahmin edilen VAR modeli, yapısal olarak tutarlı bir modeldir.

Tablo 5. Otokolerasyon LM Testi Sonuçları

\begin{tabular}{|c|c|c|}
\hline Gecikme sayıları & LM-Test İstatistik değeri & p. değeri \\
\hline 1 & 3.971640 & 0.9133 \\
\hline 2 & 6.985415 & 0.6386 \\
\hline 3 & 10.14263 & 0.3391 \\
\hline
\end{tabular}

VAR modeli $\left(\mathrm{m}+\mathrm{d}_{\max }\right)$ aşağıda belirtilen 1 . ve 2. ve denklemler yardımıyla uygulanmaktadır.

$Y_{t}=\omega+\sum_{i=1}^{m} a_{1 i} X_{t-i}+\sum_{i=1}^{m} \beta_{1 i} Y_{t-i}+\sum_{j=m+1}^{\mathrm{d}_{\max }} \delta_{1 i} X_{t-i}+\sum_{j=m+1}^{\mathrm{d}_{\max }} \theta_{1 i} Y_{t-i}+\varepsilon_{1 t}$

$X_{t}=\varphi+\sum_{i=1}^{m} a_{2 i} X_{t-i}+\sum_{i=1}^{m} \beta_{2 i} Y_{t-i}+\sum_{j=m+1}^{\mathrm{d}_{\max }} \delta_{2 i} X_{t-i}+\sum_{j=m+1}^{\mathrm{d}_{\max }} \theta_{2 i} Y_{t-i}+\varepsilon_{2 t}$

Modelde kullanılan serilerin optimal gecikme uzunluğu (m) VAR modeli aracılığıyla 1, en yüksek durağanlaşma derecesi $\left(\mathrm{d}_{\max }\right)$ ise birim kök testleri yardımıyla yine 1 olarak tespit edilmiştir. Bu doğrultuda tahmin edilen $\left(\mathrm{m}+\mathrm{d}_{\max }=1+1=2\right)$ dereceden VAR modelinde çalışmada kullanılan değişkenler arasında neden-sonuç ilişkisinin varlığını tespit etmek amacıyla $H_{0}: a_{1 i}=0$ hipotezi WALD test istatistiği ile sınanmıştır.

Tablo 6. Toda-Yamamoto (1995) Nedensellik Testi Sonuçları

\begin{tabular}{ccccc}
\hline Nedensellik & $\mathbf{m}+\mathrm{d}_{\max }$ & $\boldsymbol{X}^{\mathbf{2}}$ & p. değeri & Karar \\
\hline $\mathrm{GDP} \rightarrow$ YU & $1+1$ & 0.001348 & 0.9707 & Ho ret \\
$\mathrm{EXP} \rightarrow$ YU & $1+1$ & 6.909857 & 0.0086 & Ho ret \\
$\mathrm{EXP} \rightarrow$ GDP & $1+1$ & 1.158184 & 0.6908 & Ho kabul \\
$\mathrm{YU} \rightarrow$ GDP & $1+1$ & 0.022179 & 0.8816 & Ho kabul \\
$\mathrm{YU} \rightarrow$ EXP & $1+1$ & 0.001231 & 0.9720 & Ho kabul \\
$\mathrm{GDP} \rightarrow$ EXP & $1+1$ & 3.450023 & 0.0633 & Ho ret \\
\hline
\end{tabular}

Tahmin edilen VAR modeline dayalı Toda ve Yamamoto (1995) nedensellik testinin sonuçları Tablo 6 aracılığıyla raporlanmıştır. Tablo 6'daki test sonuçlarına göre; ekonomik büyüme ve 876 
genç işsizlik değişkenleri arasında çift taraflı nedensellik ilişkisi söz konusu değildir. Ayrıca genç işsizlikten ihracata doğru nedensellik ilişkisi mevcut olmayıp, ihracat değişkeninden genç işsizliğe doğru \%1 anlamlılık seviyesinde nedensellik ilişkisi tespit edilmiştir. İhracattan ekonomik büyümeye doğru nedensellik ilişkisinin olmadığı ancak ekonomik büyümeden ihracata doğru \%10 anlamlılık seviyesinde nedensellik ilişkisi bulunduğu, elde edilen sonuçlar arasındadır. Özetle ekonomik büyüme, genç işsizlik ve ihracat değişkenleri arasındaki ilişkinin araştırıldığı modele uygulanılan analizler neticesinde; ekonomik büyümenin $\% 10$ anlamlılık seviyesinde ihracatı, ihracatın ise \%1 anlamlılık seviyesinde genç işsizliği etkilediği, değişkenler arasında başka bir nedensellik ilişkisi bulunmadığ 1 sonucuna ulaşılmıştır.

\section{SONUÇ}

Tüm dünya ekonomilerinin temel hedeflerinden biri ekonomik büyüme sağlamaktır. $\mathrm{Bu}$ bağlamda ekonomik büyüme üzerinde etki yaratan her makroekonomik değişken kamu politikalarında araç olarak kullanılabilmektedir. Ancak söz konusu bu değişkenlerin yaratacağı etki tam olarak bilinememektedir. İktisadi çalışmalar arasında bu konu üzerinde yapılan ekonometrik çalışmaların sayısı oldukça fazladır. Ancak elde edilen sonuçların farklılık arz ettiği görülmektedir.

Türkiye'deki 1988-2019 dönemine ait genç işsizlik, ihracat ve ekonomik büyüme ilişkisinin incelendiği bu çalışmanın ampirik analiz kısmında öncelikle serilere ADF ve PP birim kök testleri uygulanmıştır. Testler sonucunda ekonomik büyüme serisinin seviyesinde diğer serilerin ise birinci farkı alındığında durağan hale geldiği görülmüştür. Dolayısıyla VAR modelinin kurulması için gerekli olan optimal gecikme uzunluğunun (m) "1" olduğuna karar verilmiştir. Bu aşamadan sonra VAR modeli kurularak optimal gecikme uzunluğu $\left(\mathrm{d}_{\max }\right)$ tespit edilmiş olup modelin istikrarlı olup olmadığı ve otokorelayon sorunu içerip içermediği araştırılmıştır.

VAR modelinin kurulmasının ardından yapılan genç işsizlik, ihracat ve ekonomik büyüme değişkenleri arasındaki neden-sonuç ilişkisini tespit etmek maksadıyla yapılan TodaYamamoto Nedensellik testine ait sonuçlar, ekonomik büyümenin \%10 anlamlılık seviyesinde ihracatı etkilediğini ancak ihracat değişkeninden ekonomik büyüme yani GSYİH'daki artış oranına doğru nedensellik ilişkisi bulunmadığını göstermektedir. Bu sonuç "Büyüme Çekişli İhracat (Growth-Driven Exports-GDE) teorisini destekler niteliktedir. İhracatın her ne kadar ekonomik büyüme üzerinde etkisi olmadığı sonucuna ulaşılsa da \%1 anlamlılık seviyesinde genç işsizliği etkilediği tespit edilmiştir. Ayrıca yapılan test sonuçları çalışmada test edilen değişkenler arasında başka herhangi bir nedensellik ilişkisi bulunmadığını işaret etmektedir.

Türkiye ekonomisi açısından ele alınan çalışma sonucunda, ihracatın ekonomik büyümeyi etkilemediği bulgusuna ulaşılmış olsa da bu durum ekonomik büyüme açısından ihracatın önemsiz olduğu anlamını taşımamaktadır. Tam aksine yine çalışmaya göre, ekonomik büyümenin ihracatı etkilediği (büyüme çekişli ihracat) ve genç işsizlik ile ihracat arasında anlamlı ilişkinin varlığını destekler nitelikte bulgulara ulaşılmıştır. Bu bağlamda, Türkiye ekonomisi açısından ihracatın ekonomik büyümeyi artırıcı etkiye sahip olmamasına neden olan problemleri ortadan kaldırıcı ve aynı zamanda ihracatın ekonomik büyümeyi artırıcı etkinliğe ulaşmasını sağlayıcı yapısal ekonomi reformlarına ihtiyaç duyulmaktadır. İhracatın ekonomik büyüme üzerinde etkinliğinin artırılması için; genç işgücünün ülke ekonomisi açısından demografik firsat penceresine dönüştürülmesine imkân tanıyabilecek genç istihdam politikalarının geliştirilmesine, teknolojik yeniliklerin üretim süreçlerine dahil edilmesine ve 
verimlilik artırıcı politikaların geliştirilerek bir an önce hayata geçirilmesine ihtiyaç duyulmaktadır.

1980 sonrası tüm dünyada yaşanan dışa açık büyüme politikaları, ihracatı ve ihracatın ihtiyaç duyacağı nitelikli genç işgücünün gerekliliği ile önemini bir kez daha ortaya koymuştur. Özellikle Türkiye'nin demografik firsat penceresi sunması bakımından sahip olduğu genç işgücünün birçok ülkeye nazaran oldukça yüksek düzeyle olduğu görülmektedir. Ancak sahip olunan bu genç işgücünün ihracat oranları ve dolaysıyla ekonomik büyümeye doğrudan katkı sunabilmesi, genç işgücünün nitelikli hale dönüştürülerek istihdam edilmesi şartına bağlanmaktadır. Genç işgücünün yüksek teknoloji üretimine katkı sunabilecek ve işgücü piyasasının aradığı niteliklere haiz seviyeye ulaştıracak istihdam politikalarıyla desteklenmesi sonucu gençlerin üretim süreçlerine dahil edilmeleri mümkün hale gelecektir. Böylelikle genç işgücü, ülke ekonomisi açısından katma değeri yüksek ürün üretiminin ve ihracatının artmasına, dolayısıyla ekonomik büyüme rakamlarına önemli bir katkı sunabilecektir. Türkiye'de özellikle son yıllarda gençlerin işgücü piyasasına geçişte yaşadıkları zorlukları ortadan kaldırıcı ve istihdam edilmelerini teşvik edici yapısal politikalar hayata geçirilmiştir. Bu durum her ne kadar Türkiye ekonomisi açısından umut verici bir gelişme olarak kabul edilse de yeterli seviyede bulunmamaktadır.

\section{KAYNAKÇA}

ACARAVCI, A. \& AKYOL, M. (2017). “Türkiye'de Doğrudan Yabancı Yatırımlar, Dış Ticaret ve Ekonomik Büyüme İlişkisi”, Uluslararası Ekonomi ve Yenilik Dergisi, 3(1): 17-33.

AKCAN A.T. \& ENER M. (2018). "Makroekonomik Değişkenlerin İşsizlik İle İlişkisi: Türkiye Örneği”, Yönetim Bilimleri Dergisi, 16(31): 263-285.

AKCAN, A. T. (2018). "İstihdam Oluşturmayan Büyümenin Türkiye Ekonomisinde Geçerliliği”, İşletme Araştırmaları Dergisi, 10(2): 171 - 183. Doi: 10.20491/isarder.2018.424

AKDİ, Y. (2003). Zaman Serileri Analizi, Birim Kökler ve Kointegrasyon. Bıçaklar Kitabevi, Ankara

AKTAŞ, C. (2009). “Türkiye'nin İhracat, İthalat ve Ekonomik Büyüme Arasındaki Nedensellik Analizi”, Kocaeli Üniversitesi Sosyal Bilimler Enstitüsü Dergisi, (18): 35-47.

AKYOL, M. (2020). “İşsizlik, İhracat Ve Ekonomik Büyüme İlişkisi: E7 Ülkeleri İçin Panel Nedensellik Analizi”. Uluslararası Katılımlı Ekonomi Araştırmaları ve Finansal Piyasalar Kongresi (ERFM), 15-16-17 Ekim 2020 Konya, Türkiye.

ALTAY, H. \& YILMAZ, A. (2016). “Türkiye'de İhracat Artışlarının İstihdam Üzerindeki Etkisinin İncelenmesi”, Finans Politik \& Ekonomik Yorumlar, 53 (616): 75-86.

ARI, A. (2016). “Türkiye’deki Ekonomik Büyüme ve İşsizlik İlişkisinin Analizi: Yeni Bir Eşbütünleşme Testi”, Siyaset, Ekonomi ve Yönetim Araştırmaları Dergisi, 4(2): 57 67 
ATA N. (2007). “Türkiye’de İşgücü Piyasasının Yapısı ve Genç İşsizlik”, TİSK Akademi, 2 (özel say1 1): 109-118.

AWOKUSE, T.O. (2007). "Causality Between Exports, Imports, and Economic Growth: Evidence from Transition Economies", Economics Letters, 94: 389-395.

AYHAN, F. (2018). “Türkiye Ekonomisinde İhracat, İthalat ve İstihdam Düzeyi İlişkisinin Uygulamalı Analizi”, Çankırı Karatekin Üniversitesi İktisadi ve İdari Bilimler Fakültesi Dergisi, 8(2): 115-135 ,DOI: 10.18074/ckuiibfd.398753

AYTAÇ, A. (2017). “Ekonomik Büyüme - İhracat İlişkisi: 2001-2016 Türkiye Örneği”, Social Sciences Research Journal, 6(4): 214-222.

BAĞCI, E. \& BÖRÜ, M. K. (2018). "Ekonomik Büyüme ve Işsizlik Arasındaki İlişki: Türkiye'de Ekonometrik Bir Analiz", International Journal of Academic Value Studies, 4(22): 890-897

BAJO-RUBIO, O. \& DIAZ-ROLDÁN, C. (2012). "Do Exports Cause Growth? Some Evidence for the New EU Members", Post-Communist Economies, 24(1): 125-131. DOI: $10.1080 / 14631377.2012 .647632$

BAYRAKTAR, S. \& İNCEKARA, A. (2013). “Türkiye'nin Genç İşsizlik Profili”, Çalışma İlişkileri Dergisi, 4(1): 15-38.

BİLGiN, C. \& SAHBAZ, A. (2009).” Türkiye'de Büyüme ve İhracat Arasındaki Nedensellik Ilişskileri”, Gaziantep Üniversitesi Sosyal Bilimler Dergisi, 8(1): 177-198.

ÇAKMUR YILDIRTAN, D. (2017). E-Views Uygulamalı Temel Ekonometri. Türkmen Kitabevi (3. Bask1), İstanbul.

ÇİFTÇI, N. \& ÇAPKIN, R. (2013). "Türkiye Ekonomisinde Cari Açık ve İşsizlik Arasındaki İlişkinin Var Tekniği ile Analizi”, İnönü Üniversitesi Uluslararası Sosyal Bilimler Dergisi, 2(2): 157-182.

ÇíL YAVUZ, N. (2006). "Türkiye'de Turizm Gelirlerinin Ekonomik Büyümeye Etkisinin Testi: Yapısal Kırılma ve Nedensellik Analizi”, Doğuş Üniversitesi Dergisi, 7 (2): 162-171.

ÇÜTCÜ, İ. \& CENGER, H. (2017). “Türkiye'de D1ş Ticaret Ve İşsizlik Arasındaki İlişki: Yapısal Kırılmalı Zaman Serisi Analizi”. III. Uluslararası Girişimcilik, İstihdam Ve Kariyer Kongresi.

DAWSON, P.J. \& SANJUÁN-LÓPEZ, A.I. (2013). "The Export-Income Relationship in Developing Countries: Evidence From Panel Cointegration", The Journal of Developing Areas, 47(1): 47-62.

DEMİRHAN, E. (2005). "Büyüme ve İhracat Arasındaki Nedensellik İlişkisi: Türkiye Örneği”, Ankara Üniversitesi Sosyal Bilimler Fakültesi Dergisi, 60(4), 75-88.

DICKEY, D. A. \& FULLER, W. A. (1981). "Likelihood Ratio Statistics for Autoregressive Time Series with a Unit Root”, Econometrica, 49(4): 1057-1072. 
DÜNYA BANKASI, "data bank", https://databank.worldbank.org/reports.aspx?source=2\&series=NE.EXP.GNFS.ZS\& country $=, 05.01 .2021$.

ERDAYI, A.U. (2009). "Dünyada Genç İşsizliği Sorununun Çözümüne Yönelik Ulusal Politikalar ve Türkiye”, Çalışma ve Toplum Dergisi, 3: 133-162.

FRANKEL, J.A. \& ROMER, D. (1999). "Does Trade Cause Growth?", The American Economic Review, 89(3): 379-399.

GÖÇER, İ. ve ERDAL, L. (2015). “The Relationship between Youth Unemployment and Economic Growth in Central and Eastern European Countries: An Empirical Analysis”. Çankırı Karatekin Üniversitesi İIBB Dergisi, 5(1): 173-188.

GROSSMAN, G.M. \& HELPMAN, E. (1993). Innovation and Growth in the Global Economy. MIT Press, Cambridge.

GURU-GHARANA, K.K. (2012), "Econometric Investigation of Relationships Among Export, FDI and Growth in India: An Application of Toda-Yamamoto-DoladoLutkephol Granger Causality Test", The Journal of Developing Areas, 46(2): 231247.

GÜL, E. \& KAMACI, A. (2012). "Dış Ticaretin İstihdam Üzerindeki Etkileri: Bir Panel Veri Analizi”, Anadolu Üniversitesi Sosyal Bilimler Dergisi, 12,(4): 23-32.

GÜRSEL, S. \& ULUSOY V. (1999). Türkiye'de İşsizlik ve İstihdam. İstanbul Yapı Kredi Yayınları, Cogito/Ekonomi-87, 1. Bask1, İstanbul.

HELPMAN, E. \& KRUGMAN, P. (1985). Market Structure and Foreign Trade. MIT Press, Cambridge.

HENDRY, D.F. \& JUSELIUS, K.(2001). "Explaning Cointegration Analysis:Part-II”, The Energy Journal, 22 (1) :75-120.

HUANG, H-C. \& LIN, S. C. (2008); “Smooth-time-varying Okun's Coefficients”, Economic Modelling, 25 (2), 363-375.

HUSSAIN, M.A. \& SAAED, A.A. (2014). "Relationship Between Exports, Imports, and Economic Growth in Saudi Arabia 1990-2011. Evidence from Co-Integration and Granger Causality Analysis", Journal of Emerging Trends in Economics and Management Sciences (JETEMS), 5(3): 364-370.

İGİ, B.B. \& YILMAZ, H. (2018). “Türkiye'de Ekonomik Büyüme, İhracat ve İthalat: Nedensellik İlişkisi (1992-2016)", İktisadi Yenilik Dergisi, 5(2): 54-74

KADERLİ, Y. \& KÜÇÜKKAYA, H. (2012). "2008 Dünya Finansal Krizi Sonrası Türkiye Ekonomisinde Yaşanan Gelişmelerin Bazı Ülkelerle Karşılaştırmalı Olarak İncelenmesi", Pamukkale Üniversitesi Sosyal Bilimler Enstitüsü Dergisi, 12: 85-96.

KATUMO, M.D. \& MAINGI, J. (2020). "Relationship between Youth Unemployment and Economic Growth in Kenya". Advances in Economics and Business 8(5): 255-267. 
KIGABO, T. R. \& KAMANZI, C. (2018). “Job Creating Growth and Governance: The Case of Rwanda. East Africa Research Papers in Economics and Finance”, EARP-EF No. 2018: 31 .

KREISHAN, F. (2011). "Economic Growth and Unemployment: An Empirical Analysis", Journal of Social Sciences, 7(2): 228-231.

LÉAUTIER, F. A. \& HANSON, K. T. (2013). "Jobless Economic Growth: Lessons From Africa", ACBF Working Paper No. 25: 5.

MURAT, S. \& YILMAZ-ESER, B. (2013). “Türkiye'de Ekonomik Büyüme ve İstihdam İlişkisi: İstihdam Yaratmayan Büyüme Olgusunun Geçerliliği’, HAK-İŞ Uluslararası Emek ve Toplum Dergisi, 2(3): 92-123.

MURATOĞLU, Y. (2011). "Büyüme İstihdam Arasındaki İlişki Türkiye Örneği”, International Conference On Eurasian Economies, http://www.eecon.info/papers/335.pdf

PERRATON, J. (2011), "Explaining Growth? The Case of the Trade-Growth Relationship", Journal of Economic Methodology, 18(3): 283-296.

PHILLIPS, P. \& PERRON, P. (1988).” Testing For A Unit Root in Time Series Regressions”, Biometrica, 75(2): 335-346.

RAMOS, F.F.R. (2001). "Exports, Imports, and Economic Growth in Portugal: Evidence from Causality and Cointegration Analysis" Economic Modelling, 18: 613-623.

RANGASAMY, L. (2009). "Exports and Economic Growth: The Case of South Africa", Journal of International Development, 21 (5): 603-617.

SARAÇ, T.B. (2013). "İhracat ve İthalatın Ekonomik Büyüme Üzerindekí Etkisi: Türkiye Örneği", Ege Akademik Bakış, 13(2): 181-194.

SEYİDOĞLU, H. (2013). Uluslararası İktisat: Teori, Politika ve Uygulama. 19.Baskı, Güzem Can Yayınları, İstanbul.

ŞAHİN, H. (2014). Türkiye Ekonomisi. Gözden geçirilmiş ve genişletilmiş 14. Baskı, Ezgi Kitabevi, Bursa.

TAKIM, A, (2010). “Türkiye'de Ekonomik Büyüme İle İşsizlik Arasındaki İlişki: Granger Nedensellik Testi”, Dumlupınar Üniversitesi Sosyal Bilimler Dergisi , (27), https://dergipark.org.tr/tr/pub/dpusbe/issue/4769/65618

TEJANI, S. (2016). "Jobless Growth in India: An Investigation", Cambridge Journal of Economics, 40: 843-870.

TEMIZ, D., \& GÖKMEN, A. (2010). “An Analysis Of The Export And Economic Growth In Turkey Over The Period Of 1950-2009”. International Journal of Economic and Administrative Studies, 2(5): 124-142

TODA, H. Y., \& YAMAMOTO, T. (1995). "Statistical İnference İn Vector Autoregressions With Possibly İntegrated Processes”, Journal Of Econometrics, 66(1): 225-250 
USLU, H., (2018). "Ekonomik Büyüme ve İşsizlik İlişkisinin Türkiye Ekonomisindeki Yeni Gelişmeler Çerçevesinde İncelenmesi”, Social Sciences Studies Journal, 4(20): 15151531.

VILLAVERDE, J. \& MAZA, A. (2009). “The Robustness of Okun's Law in Spain, 1980- 2004 Regional Evidence", Journal of Policy Modeling, 31 (2): 289-297.

YAMAK, R., ABDİOĞLU, Z. \& MERT, N. (2012). “Türkiye'de İşgücüne Katılımı Belirleyen Faktörler: Mikro Ekonomik Analiz”, Anadolu Üniversitesi Sosyal Bilimler Dergisi, 12 (2): 41-59.

YAPRAKLI, S. (2007). "İhracat ile Ekonomik Büyüme Arasındaki Nedensellik: Türkiye Üzerine Ekonometrik Bir Analiz”, ODTÜ Gelişme Dergisi, 34(1): 97- 112.

YÜKSELER, Z. \& TURKAN, E. (2008). “Türkiye'nin Üretim ve Dış Ticaret Yapısında Dönüşüm: Küresel Makroekonomik Yönelimler ve Yansımalar”, TUSİAD Yayınları, No:TUSİAD-T/2008-02/453: 163. 